\title{
Overview of Stress Levels Factors in Students During Online Learning During The Covid-19 Pandemic in 2021
}

\author{
${ }^{1}$ Festia Dwi Cahyani, ${ }^{2}$ Fitri Rahmaningsih, ${ }^{3}$ Hilda Nurul Fadillah, ${ }^{4}$ Lia Ambarwati, ${ }^{5}$ Munaya \\ Fauziah \\ 1,2,3,4,5 Faculty of Public Health, Muhammadiyah University of Jakarta \\ K.H Ahmad Dahlan St, Cirendeu, Ciputat, South Jakarta, 15419 \\ E-mail: ambarliawati22@gmail.com
}

\begin{abstract}
The government orders all learning activities to be carried out at home (learning from home) and working from home (Work From Home/WFH). because online learning has been going on for more than a year in Indonesia, therefore, this study aims to analyze the factors that affect the level of stress in students during online learning during the 2021 Covid-19 pandemic. This study aims to analyze the factors that influence the stress level of students during online learning. This research was conducted for 1 month, namely June 2021. This study uses a qualitative method with a phenomenological approach. Data collection comes from in-depth interviews with 6th-semester students and a sample of 4 students is taken. During online or online learning that students do during the Covid-19 pandemic, it affects the stress level of 6th-semester students who will soon graduate. Factors that affect the level of stress in students include internal stressors, external stressors, and stress symptom factors (psychological symptoms, physical symptoms, and behavioral symptoms). The factors that affect the level of stress in students during online learning during the Covid-19 pandemic are internal stressors, external stressors, and stress symptom factors.
\end{abstract}

Keyword: Stress level factors, Online learning, Covid-19 


\section{INTRODUCTION}

The Covid-19 pandemic first appeared in the city of Wuhan, China in November 2019, which made people around the world feel worried. The spread of Covid-19 around the world is spreading very fast. Many people around the world have been exposed to this virus. This has caused governments in various countries to make policies to prevent the spread of Covid-19 by locking it down. Where Lockdown itself is a policy to temporarily stop all existing activities. so that in the end every country enforces a stay-at-home policy for the whole community.

Online learning is a learning activity by utilizing the internet network, local area network as a method of interacting in learning such as delivering material. Online learning can be done with a computer, laptop, or smartphone facilities that are connected to the internet network. With this facility, lecturers and students can study together at the same time using platforms such as WhatsApp, telegram, zoom, meets, and google classroom (Jatira, 2021).

COVID-19 has been designated by the World Health Organization (WHO) as a global pandemic, which has prompted the Indonesian government to implement several strategic policies to prevent and minimize the spread of Covid-19. Indonesia has also implemented a lockdown, just like several other countries in the world by imposing PSBB (Large-Scale Social Restrictions). Based on the Circular of the Minister of Education and Culture Number 36962/MPK.A/HK/2020, the government ordered all learning activities to be carried out at home (learning from home) and working from home (Work From Home/WFH). This government regulation has an impact on students in higher education. Lecture activities are carried out remotely with the help of supporting applications. Various kinds of social media can be used by students to assist in doing assignments, reporting lecture activities, and undergoing the lecture process online (et al., 2020).

Academic stress is caused by academic stressors, namely stressors that start from the learning process such as pressure to get good grades, length of the learning process, many tasks to complete, low grades, and anxiety in facing exams. Basel et al., 2017 explained that academic stress is the pressure caused by a subjective perspective on an academic condition. The results of the research by Siregar and Putir (2019) explain that academic stress is influenced by Self-Efficacy with a negative correlation. Another study conducted by Liu (2011) states that $90 \%$ of students experience academic stress due to exams, lack of achievement, delays in assignments, homework, an unsupportive school climate, as well as confidence and willingness to learn. because online learning has been going on for more than a year, this study aims to determine the factors that affect the level of stress in students during online learning during the COVID-19 pandemic in 2021 (et al., 2020).

\section{METHODS}

This study aims to describe the stress level of 6th-semester students during online learning during the COVID-19 pandemic in 2021. This type of qualitative research was carried out by four 
informants at the same level but different universities. Source triangulation was carried out on four informants to determine the factors that influence the level of stress in students during online learning during the Covid-19 pandemic.

This study uses a qualitative method with a phenomenological approach. Data collection comes from in-depth interviews which are then copied in the form of words or writing. This research is research conducted on 6th-semester students and a sample of 4 students is taken. The research time lasted for 1 month, namely June 2021. 4 informants were interviewed in June 2021. Interviews were conducted via mobile phones to avoid contact during the pandemic. the sources of information or informants in this study were 6th-semester students.

Informants who will be conducting in-depth interviews are 4 informants who have an overview of the stress level of online learning during this Covid-19 pandemic. informants were selected based on availability, adequacy criteria, and representation in explaining the answers to the questions in this study. The informants have the initials MR (21) semester 6, A (21) semester 6, RA (21) semester 6, MA (21) semester 6. There are two types of data sources used in this study, namely primary data and secondary data. Primary data is specifically carried out to answer research questions. The writer collects primary data by survey method and observation method. while secondary data is obtained from data collection techniques that support primary data.

This study was obtained from the results of observations made by the author as well as from literature studies related to this research. To maintain the validity of the data, to determine the validity of the data in this study, two triangulations were used, namely source triangulation and method triangulation. Source triangulation was carried out using in-depth interviews with predetermined informants using a research instrument in the form of interview guidelines. Method triangulation is done using in-depth interviews and observation of data from literature studies. Researchers use this triangulation to ensure the accuracy of the data collected. Researchers discussed the findings of indepth interviews and data observations with the research team and the experts.

The processing and analysis of qualitative data in this study were carried out by rewriting the data from the interview notes where the data was transferred in the written form completely without changing, adding, or subtracting the information contained in the interview notes. Then a descriptive data analysis was carried out so that conclusions were obtained from the data that had been processed by coding each resource person's answers contained in table 1 .

Tabel 1. Contoh Tabel Analysis Content

\begin{tabular}{|c|c|c|c|c|}
\hline & Code & Sub-category & Category & Theme \\
\hline 1. & $\begin{array}{l}\text { Anxious and } \\
\text { panic }\end{array}$ & Psychological Symptoms & Stress Level & $\begin{array}{l}\text { Stress level factor in } \\
\text { students }\end{array}$ \\
\hline 2. & Hurry & & & \\
\hline 3. & Confused & & & \\
\hline 4. & Not calm & & & \\
\hline
\end{tabular}


Tabel 2. Contoh Tabel Synthesis

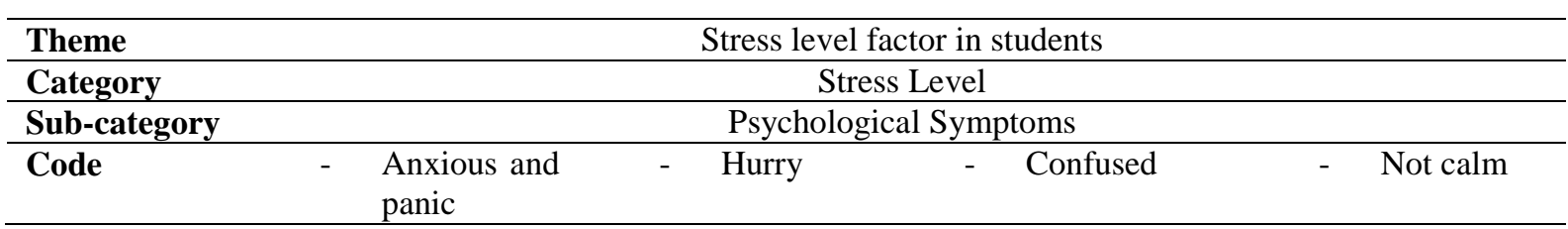

\section{RESULTS AND CONCLUSIONS}

Characteristics of research respondents conducted on 4 students who are in the 6th semester. From this study, the following results were obtained which were conducted in-depth interviews with 4 6th semester students.

Based on the results of interviews with informants about how to overcome health problems during online learning, the following are the results of the interviews:

"Yeah, maybe if you're really tired, then you can zoom in while studying by switching it off and not listening to it when you're not playing social media, but if you're messed up while watching drama. The most family and friend support system".

"Reducing the lighting on the laptop, and I wear anti-radiation glasses so as not to increase the risk of eye disease".

"If I think about it, it's most often interspersed with other activities, playing at a friend's house or doing other things."

"When I'm usually online, I'm not always on cam, so I squeeze in when I'm off cam to stretch it so that my eyes don't get sore every 20 minutes I look at distant objects or something cool so that my eyes don't strain too."

Based on the results of this study, it was found that the majority of informants maintain their health condition by doing other things/activities. Some divert it by playing social media, watching dramas, using anti-radiation glasses to prevent eye pain and stretching for 20 minutes, and looking at cool objects so that they relax the eyes. according to the results of research conducted by Mutisari (2010) that overcoming burnout symptoms can be done with several controls such as emotional control, positive thinking, and mutual support from others (Hartanti, Supriyanto, and Ulfatin, 2018). Health is an important factor to improve the quality of life. Health is very important for humans. Every human being has the right to be healthy and must maintain his health.

Based on the results of interviews with informants regarding the feelings of informants when they have to manage time to be able to complete tasks with tight deadlines, here are the results of the interview:

"If you have a lot of deadlines, you can say that you are anxious, you are anxious, but we think, why to worry too much, panic too much, so it's better to pay in installments, continue, work on that, I mean, don't panic when the deadline is too much." 
"I feel like I'm in a rush and I'm working on it right away, even though the time is very tight."

"I'm confused which one to do first because it's not just one markup, there are several, especially the deadlines are close, that's all."

"I feel like I'm nervous, I'm nervous, I'm not calm like that, I feel like I'm not calm because I'm being chased by a task deadline".

The results of the interview showed that in doing the task, the majority of informants only did it when it was close to the collection deadline because some of the informants were confused about which task to do first, but some informants had already shared their tasks with good so that you still feel calm and not too anxious when the deadline is near. research conducted by Haynes (in Agustamanesia 2017) says time management like other resource management relies on analysis and planning. To understand and acquire the principles of time management, it is necessary to know not only how to use time, but also the problems of using time effectively. people who can use time effectively are people who can prioritize important tasks first (Agustamanesia, 2017)

Learning motivation is a condition that encourages students to achieve what they want in attending higher education. Motivation in learning is needed by students. based on the results of interviews with informants regarding student learning initiatives/motivations during online learning, here are the results of the interviews:

"Actually, before Eid, there is a sense of initiative to do group or individual assignments, just because you are rich since, after Lebaran, there are many tasks that you are confused about which one to do first, so it's best to increase the initiative to find time for other tasks." (Initials: MR)

"Yes, I always put my work first so it doesn't pile up too much." (Initials: A)

"There is no initiative at all, trying not to think about other things besides studying besides studying. Because when you think about other things, your thoughts get mixed up in your head." (Initials: RA)

"Yes, there is, to maintain it, we continue to do it, such as preparing favorite foods during online learning as well as when doing assignments so that we don't get bored, get bored, sometimes do assignments while studying but try to stay focused." (Initials: MA)

From the results of the interview, it was found that student motivation was seen from the initiative to do assignments, some students still had motivation in completing assignments. students do several activities to get rid of boredom and boredom during online learning so that assignments can still be done and lectures can stay focused. the results of this study are in line with research conducted by Stefania et al in 2020 that there is a relationship between motivation and stress levels of students in doing assignments, especially final assignments (Seto, Wondo, and May 2020).

Stress on students can arise because of problems with family, lecturers, campus friends, boarding friends, and so on. This problem occurs because there is no good relationship between each 
other. good relations with lecturers, campus friends, and boarding friends, can make students more motivated to be enthusiastic about learning.

Based on the results of interviews with informants regarding parental support to students during online learning, the following are the results of the interviews:

"There are parents who ask where they go, it doesn't reduce stress just because parents need to go." (Initials: MR)

"I am often given support from my parents so that I am enthusiastic in doing the task." (Initials: A)

"There is no si at all." (Initials: RA)

"Yes, usually when my mom is on vacation or when I don't have a class schedule, she likes to ask me out, for shopping, whether it's clothes or food." ." (Initials: MA)

The results of the interviews showed that some students had a supportive social environment, seen from their parents who gave support in the form of enthusiasm and invited them to go out to find a new atmosphere and calm down. but there is a student who has a less supportive social environment because he does not get support or enthusiasm from his parents. This is by research conducted by Yuliatun in 2012 that there is a significant influence between the social environment on learning achievement. one aspect of the main social environment, namely the family environment that affects one's learning success, especially during this online learning (Yuliatun, 2012).

Based on the results of the study as many as 3 students felt that their worship was affected by online learning. The effect is felt, namely neglecting to pray more prioritizing tasks so that prayers at the end of time even don't carry out prayers. other students whose worship is not affected during online learning because they make prayer a priority. According to them, how to calm themselves and their minds according to their religious teachings can be done by reading the letter Ar-Rahman, listening to mortal, praying, praying, doing istigfar, and positive thinking.

Different from the results of research conducted by Damar in 2017 that there is a negative relationship between spirituality and stress in students who are working on a thesis. The higher the spirituality, the lower the stress, the lower the spirituality, the higher the stress. This is in line with the research by McClain-Jacobson, et al in 2004 which states that the higher the level of spirituality, the lower the level of psychological distress such as stress, depression, hopelessness, desire to die, and suicidal ideation in seriously ill patients (Aditama, 2017).

The non-social environment can also cause students to experience stress during the learning process. The social environment can be caused by natural environmental factors and instrumental factors. based on the results of interviews with informants on how to overcome when experiencing signal disturbances during online learning, here are the results of the interviews: 
"For example, if the tasks are piled up, I'll make a list so I can work on it, if the signal is over it, install wifi, but first look at the comparison, how about installing wifi, how do you talk to your parents and the quota is swelling, ask your parents for money because there is no income."(Initials: $M R)$

"If I have a problem, I don't hear the lecturer's voice, most of the time I record it and then I listen to it again, my parents don't pressure me to get good grades if you have internet quota, you usually get a quote from the government, in my opinion, the burdens are the problem."(Initials: A)

"I'm at home using wifi so maybe the network is better than data, but the wifi also has problems."(Initials: $R A)$

"Sometimes when I'm in college, my quota runs out, so I don't want to have to go out and buy a quota. but if for example, the network at home is bad, at least I change the network using wifi but sometimes the wifi doesn't like the network is stable."(Initials: MA)

The results of these interviews indicate that the majority of informants use wifi. when online learning is taking place and the network is unstable they switch to using wifi. The internet quota that students use comes partly from government subsidies which every month provide free quota assistance for students. but sometimes the wifi network can also experience interference so that online learning is a little disrupted. The results of this study are in line with those of Vibrianti (2020) who said that several universities in Indonesia felt they were not ready to carry out online or, distance learning. Some of the problems that arise related to online learning are student readiness, mastery of technology, short time, lots of assignments, number of quotas, and poor signals (Fauziyyah, Awinda, and Besral, 2021).

One of the aspirations of high school graduates is to be a student and study at a favorite university. Studying in college is not easy. There are many academic demands that students must be able to do. These demand rates stress students. based on the results of interviews with informants regarding the effect of online learning on students' stress levels, the following are the results of the interviews:

"Hmm, it affects stress levels because many tasks become stressful." (Initials: MR)

"Yeah, I often experience it when I have a lot of work to do." (Initials: A)

"Yes, very influential. Waiting for the lecturer, it's not clear what time he comes in, sometimes, it's suddenly canceled and the assignments are a lot like that, that's all. (Initials: RA)

"It's influential, especially since I major in nursing, I practice a lot because I'm online, so it affects. plus a full-day class schedule." (Initials: MA)

The results of the interview above show that during the learning process students experience many difficulties in receiving the material provided by the lecturer because in this online learning there is a lack of interaction which makes students feel less than optimal in their learning. this is also 
in line with research conducted by Nurmala et al, 2020 the feelings of stress faced by students when facing online learning can be seen from the responses of students who complain of discomfort, difficult signals, limited quotas, and difficult networks in the area stay them. according to Kompas $\mathrm{TV}, 2020$ found facts in the field that another obstacle for students participating in online learning is that they think distance communication is not optimal compared to direct communication (M. Nurmala, T. Wibowo, 2020).

Based on the results of interviews with informants about how students manage anger during online learning, here are the results of the interviews:

"No, the way to hold it is maybe as much as possible to hold back by looking at funny things, reading quotes to make yourself aware." (Initials: MR)

"Yes, the way to deal with it I like to calm myself when my emotions have been dampened." (Initials: A)

"Yeah, so the more angry way to handle it is to lie down and take a breath that's the most." (Initials: RA)

"Yes, I have, the way to relieve it is usually to grumble first, then usually after that shifting to other things, such as playing on a cellphone, venting with friends like that." (Initials: MA)

The results of the interview above show that from the results of research conducted on four students, it was found that three out of four students felt easily angry about trivial things and one of them did not feel it. and of the four students, three of them felt less stressed and did not overreact to what was being faced and preferred to enjoy me while one of them was easily depressed by what was happening. of the four students, three of them felt hampered by the tasks given and one of them did not feel that way. for these four students, when they were experiencing disturbances during online learning, they were more diverted to activities that calmed the brain and mind such as resting first, watching YouTube, and buying favorite foods to raise the mood again.

Based on the results of research conducted by Livana et al,. (2020) the most common cause of student stress during the Covid-19 pandemic is lecture assignments. the number of tasks that are considered excessive with the demands of a relatively fast collection time makes the mental health of students disturbed. Students become unable to rest enough because many tasks must be prioritized first (Kartika, 2020).

Based on the results of interviews with informants regarding student responses when they cannot understand the things that get in the way of completing coursework during online learning, here are the results of the interview:

"I try to make time to do the task first" (initials: A)

"No, it's like I'm working on a task and then suddenly my mother has a sudden event like that. Yes, my response made the most of the invitation, so I just went along because at the same time 
refreshing my brain when I was dealing with a laptop, that's how I can refresh my brain" (initials: $M$ $R)$

"Yes, I'm confused, then just do it, the important thing is to finish" (initials: RA)

"I'm a bit annoyed, right, because there are a lot of assignments, most of them are in groups, so I'm just annoyed if I can't finish it" (initials: (MA)

Based on the results of research that has been carried out on four 6th semester students, it shows that the majority of students can complete assignments quickly. but the influence of online learning according to informants makes them want to finish their tasks quickly so they don't pile up and multiply. Online learning in its implementation has obstacles. The first obstacle, some children do not have a gadget (HP). the second obstacle is having a cell phone, but the cellphone facilities and internet connection are hampered, hampered in sending assignments because of the difficult signal. Even further data explains that some students do not have their cellphones, so they have to borrow.

The third obstacle is that parents have cellphones but parents work all day outside the home so that parents can only accompany them at night. The fourth obstacle is the limited internet connection, some students do not have cellphones and the internet network is not good. the fourth obstacle, not all children have HP facilities and some parents are not savvy with technology. This makes it difficult for parents to accompany and facilitate their children (Anugrahana, 2020).

Based on the results of interviews with informants about students' feelings when they feel anxious and affect their body energy, the following are the results of the interview:

"No, I'm just trying to accept that" (initials: $M R$ )

"I feel anxious when the time for submitting assignments is very tight" (initials: A)

"Yeah, that's often every day. So tired, so if you want to do the task, there is no energy, no energy" (initials: RA)

"I've never had a lot of energy, I'm usually worried, I just don't calm down like that" (initials: $M A)$

Based on the results of research that has been done, it shows that the majority of informants think that anxiety often occurs because they are too tired with many online learning tasks and tight collection times so that sometimes it makes them feel anxious and affects the levels of stress. According to research, the anxiety experienced by students varies because anxiety is a form of individual emotion related to a sense of being threatened by something, usually with a threat object that is not so clear. Anxiety can be experienced by anyone and anywhere, including students at school. Anxiety experienced by students at school can be in the form of objective anxiety, neurotic (nervous), or moral anxiety (Mukholil, 2018).

\section{CONCLUSIONS AND SUGGESTIONS}


Based on the results and discussion of the research, it can be concluded that the level of stress during online learning harms students. Stress can be felt by students when the stress exceeds their ability to deal with it. In particular, stress can hurt students' learning conditions and cognitive abilities. Factors that affect the level of stress in students during online learning during the Covid-19 pandemic are internal stressors, external stressors, and stress symptom factors such as psychological symptoms, physical symptoms, and behavioral symptoms.

The results of the study on the description of the stress level of students during online learning during the Covid-19 pandemic showed that all students who were in the research sample experienced stress during online learning or online lectures and this affected student activities and worship during this Covid-19 pandemic. Therefore, we recommend the following, first, it is hoped that the university can facilitate student consultation activities with psychologists regarding mental health for students during online learning. In addition, the lecturers and the academic community need to innovate in the learning process, such as when starting lectures, the lecturer invites students to do sports or stretch for a while so that they are not bored and do not experience physical disturbances. Second, students are expected to be able to maintain mental and physical health during online learning so that they are always enthusiastic in carrying out lectures.

\section{REFERENCES}

Aditama, D. (2017) 'Hubungan antara spiritualitas dan stres pada mahasiswa yang mengerjakan skripsi', Jurnal eL-Tarbawi, 10(2), pp. 39-62.

Agustamanesia, E. D. R. (2017) 'Tingkat Kemampuan Mengelola Waktu Mahasiswa (Studi Deskriptif pada Mahasiswa yang Terlibat dalam Organisasi Badan Eksekutif Mahasiswa Universitas Sanata Dharma Tahun Ajaran 2016/2017)', Thesis, pp. 1-36.

Anugrahana, A. (2020) 'Hambatan, Solusi dan Harapan: Pembelajaran Daring Selama Masa Pandemi Covid-19 Oleh Guru Sekolah Dasar', pp. 282-289.

et al. (2020) 'Analisis Tingkat Stres Akademik Pada Mahasiswa Selama Pembelajaran Jarak Jauh Dimasa Covid-19', Biblio Couns : Jurnal Kajian Konseling dan Pendidikan, 3(1), pp. 10-14. doi: 10.30596/bibliocouns.v3i1.4804.

Fauziyyah, R., Awinda, R. C. and Besral, B. (2021) 'Dampak Pembelajaran Jarak Jauh terhadap Tingkat Stres dan Kecemasan Mahasiswa selama Pandemi COVID-19', Jurnal Biostatistik, Kependudukan, dan Informatika Kesehatan, 1(2), p. 113. doi: 10.51181/bikfokes.v1i2.4656.

Hartanti, I. D., Supriyanto, A. and Ulfatin, N. (2018) 'Manajemen Penanganan Burnout Dalam Meningkatkan Kinerja Tenaga Administrasi Sekolah', Jurnal Administrasi dan Manajemen Pendidikan, 1(3), pp. 347-357. doi: 10.17977/um027v1i32018p347. 
Jatira, Y. (2021) 'EDUKATIF: JURNAL ILMU PENDIDIKAN Fenomena Stress dan Pembiasaan

Belajar Daring Dimasa Pandemi Covid-19', Jurnal Ilmu Pendidikan, 3(1), pp. 35-43. Available at: https://doi.org/10.31004/edukatif.v3i1.187.

Kartika, R. (2020) 'Analisis Faktor Munculnya Gejala Stres Pada Mahasiswa Akibat Pembelajaran Jarak Jauh Di Masa Pandemi Covid-19', Edukasi Dan Teknologi, 1(2), pp. 107-115. Available at: https://www.researchgate.net/profile/Abdul_Latip/publication/341868608_PERAN_LITERA SI_TEKNOLOGI_INFORMASI_DAN_KOMUNIKASI_PADA_PEMBELAJARAN_JARA K_JAUH_DI_MASA_PANDEMI_COVID-19/links/5ed773c245851529452a71e9/PERANLITERASI-TEKNOLOGI-INFORMASI-DAN-KOMUNIKASI.

Mukholil (2018) 'KECEMASAN DALAM PROSES BELAJAR'.

M. Nurmala, T. Wibowo, A. R. (2020) 'Tingkat Stres Mahasiswa Dalam Pembelajaran Online Pada Masa Pandemi Covid-19’, Jurnal Penelitian Bimbingan dan Konseling, 5(2), pp. 13-23.

Seto, S. B., Wondo, M. T. S. and Mei, M. F. (2020) 'Hubungan Motivasi Terhadap Tingkat Stress Mahasiswa Dalam Menulis Tugas Akhir (Skripsi)', Jurnal Basicedu, 4(3), pp. 733-739. doi: 10.31004/basicedu.v4i3.431.

Yuliatun, 2012. PENGARUH LINGKUNGAN SOSIAL DAN MOTIVASI BELAJAR TERHADAP PRESTASI BELAJAR EKONOMI PADA SISWA KELAS VIII MTS AL IRSYAD NGAWI TAHUN AJARAN 2011/2012. 
Volume I Tahun 2021

November 2021
E-ISSN: 2808-5361

http://e-journal.fkmumj.ac.id/
Proceeding The First Muhammadiyah InternasionalPublic Health and Medicine Conference 